\title{
Cooperation from Outside: Security Regionalism in Central Asia and Its Limits
}

\author{
Sebastian Mayer \\ DAAD Associate Professor of International Relations, Head Centre for \\ Research \& Graduate Education, Kazakh-German University, Almaty, \\ Kazakhstan, and Associated Researcher InIIS, University of Bremen, \\ Bremen, Germany \\ mayer@dku.kz
}

\begin{abstract}
The degree of institutionalized cooperation on security among three or more of the five Central Asian states remains moderate. Currently, regional security is nurtured in part via frameworks provided by external state and nonstate partners. A rational institutionalist perspective has been invoked, suggesting demand for regional security cooperation. This view also insinuates that it would be reasonable for these five states, because of their limited resources, to rely largely on external cooperation partners instead of being self-organized. This article discusses additional causal factors possibly responsible for the low degree of regionalism. Given varying foreign policy preferences and Kazakhstan's consistent backing of far-reaching security regionalism, the argument that autocracies generally refrain from deep security cooperation cannot be sustained, nor does the sea change in Uzbekistan's foreign policy in 2016, which could serve to nurture security regionalism in the future, align well with this argument.
\end{abstract}

\section{Keywords}

Central Asia - security cooperation - regionalism - regional organizations 
This article discusses intergovernmental security cooperation among the five states of Central Asia-Kazakhstan, Uzbekistan, Kyrgyzstan, Tajikistan, and Turkmenistan. Specifically, it delineates the process of regionalism that has to a certain extent occurred since these states gained independence in 1991 and became more decentralized. With the end of the Cold War and the disappearance of the overarching lens of bipolarity, security policies have generally become more regionalized, and these regional developments have acquired strong dynamics of their own. As can be seen in different regions of the world, states have begun taking their affairs into their own hands and have explored new specific and more independent security arrangements. Hence, there are more formal regional security arrangements—or increased instances of institutionalization - that vary in scope, complexity, and strength. Examples include the African Union (AU), which was established in 2002, and the European Security and Defense Policy (ESDP), which likewise started evolving in the early 2ooos. Regions now enjoy greater autonomy from system-level forces and have fostered a regional reordering of world politics. ${ }^{1}$

The absence of interstate violence, large-scale mistrust and separatism distinguishes Central Asia from more precarious regions such as the Southern Caucasus or the Middle East. This absence appears to allow for significant cooperation among the five states, which also have certain features and challenges in common, including their Soviet past, similar authoritarian polities, and comparable security challenges (e.g., terrorism and drug trafficking). Since 1991, their leaders have evoked these notions of a shared history and heritage. Being able to take their fate into their own hands led to the vision of an integrated union of the Central Asian states. Regional integration and the notion of a "common regional identity" remain key topoi among practitioners and scholars alike-especially since 2016, when Uzbekistan's new president became more amenable to cooperation with his neighbors. To date, however, such cooperation has remained modest. An exclusive regional (security) organization has yet to be created that would include all five states and no more than these states-which would be a strong sign of regionalism. The

1 E.g., Barry Buzan and Ole Wæver, Regions and Powers: The Structure of International Security (Cambridge: Cambridge University Press, 2003); Peter J. Katzenstein, A World of Regions: Asia and Europe in the American Imperium (Ithaca, NY: Cornell University Press, 2005). 
existing security institutions, which comprise most or all of the five states, remain weak. ${ }^{2}$

This article assesses related bilateral and multilateral efforts to self-organize within the region and highlights the associated impacts of outside actors on regionalism as a way to discern cooperation dynamics and their limits in Central Asia. The insights from this assessment can contribute to the literature on "cooperation among autocracies," which seeks to identify across-case attributes that influence variations in cooperation beyond the liberal democratic world. Although this article broadly subscribes to rational institutionalist theory, it remains predominantly inductive, with institutionalism used as a generic framework through which to view the empirical data. A number of potentially causal factors are invoked with the aim of providing informed assumptions.

The key argument presented here is that the degree of security regionalism in Central Asia and hence the measure of self-organization remain modest. To an extent, regional cooperation is nurtured via frameworks provided by external cooperation partners. The rational institutionalist perspective suggests that there is a demand for regional security cooperation. Likewise, it implies that it would be reasonable for the five states, whose resources are limited, to rely largely on external cooperation partners rather than on self-organization.

The next section situates the theme of regionalism within the context of the relevant literature, broaching insights on Central Asia in particular and, more generally, the concept of cooperation beyond established democracies. In addition, this section will serve to clarify the methodology used and to define certain terms. The third section will identify key security challenges in Central Asia and discuss the possible benefits of joint problem-solving. In line with the rational institutionalist perspective, the question arises of whether there is in fact a demand for cooperation-something that Central Asia scholars often take for granted. The subsequent two sections outline the development and current status of cooperation among the five states, as well as the respective impacts of external security actors, and note that only a small degree of regionalism was detected. The penultimate section presents a number of factors that may explain the current low degree of cooperation, while the final one sums up the findings.

2 Marlène Laruelle and Sebastien Peyrouse, Regional Organisations in Central Asia: Patterns of Interaction, Dilemmas of Efficiency (Bishkek: University of Central Asia, Institute of Public Policy and Administration, 2012). 
The existence of regionalism implies that state-led regional cooperation has become increasingly deep. This is evidently true of regions with established liberal democracies. Nevertheless, the empirical record shows that autocratic states are often more reluctant in this regard, above all in the security realm. For instance, although the Association of Southeast Asian Nations (ASEAN) has shown a commitment to multilateralism, ${ }^{3}$ this community exhibits constraints when it comes to security cooperation. ${ }^{4}$ According to Costa Buranelli, Central Asia adheres to an "illiberal solidarism," that is, counter-discourses and practices against the external promotion of democracy. ${ }^{5}$ Mansfield and his collaborators argued that autocracies are fundamentally less willing than democracies to cooperate with one another because they fear that marked cooperation might jeopardize their ability to maintain their regimes. ${ }^{6}$ Somewhat in line with Costa Buranelli's view, one argument is that autocratic states establish regional organizations merely to ensure regime survivalnot to reap the overall benefits of cooperating. ${ }^{7}$ Resembling Kantian liberal thought, a more constructivist claim is that autocracies simply lack trust and are therefore reluctant to cooperate with other states to any great extent. ${ }^{8}$

Although research has been done on the issue of cooperation in Central Asia, these studies are largely confined to less politically charged fields such as

3 Amitav Acharya, Constructing a Security Community in Southeast Asia: ASEAN and the Problem of Regional Order (London: Routledge, 2001).

4 Donald K. Emmerson, Will the Real ASEAN Please Stand Up? Security, Community and Democracy in Southeast Asia (Stanford, CA: Stanford University Press, 2005).

5 Filippo Costa Buranelli, "Authoritarianism as an Institution? The Case of Central Asia," International Studies Quarterly 64, no. 4 (2020): 1005-16.

6 Edward D. Mansfield, Helen V. Milner and B. Peter Rosendorff, "Why Democracies Cooperate More: Electoral Control and International Trade Agreements," International Organization $5_{6}$, no. 3 (2002): 477-513. See also Oisín Tansey, Kevin Koehler and Alexander Schmotz, "Ties to the Rest: Autocratic Linkages and Regime Survival," Comparative Political Studies 5o, no. 9 (2017): 1221-54.

7 Roy Allison, "Virtual Regionalism, Regional Structures and Regime Security in Central Asia," Central Asian Survey 27, no. 2 (2008): 185-202; Alexander Libman and Anastassia V. Obydenkova, "Regional International Organizations as a Strategy of Autocracy: The Eurasian Economic Union and Russian Foreign Policy," International Affairs 94, no. 5 (2018): 1037-58.

8 Anastassia V. Obydenkova and Alexander Libman, "Security Regionalism: The SCO," in Authoritarian Regionalism in the World of International Organizations: Global Perspective and the Eurasian Enigma, ed. Anastassia V. Obydenkova and Alexander Libman (Oxford: Oxford University Press, 2019), 219-55. 
economics, trade, and the environment. ${ }^{9}$ Considerably less scholarship exists regarding the field of security. What little there is centers on questions of order or perceptions of threat, not on integration dynamics or the lack thereof. ${ }^{10}$ One reason for this neglect might be that interstate relations in Central Asia are widely cast in realist terms, whereby durable security cooperation seems simply inconceivable. The associated assumption is that in this policy field, governments value autonomy over cooperation, because cooperation would impede survival. Often cited but rather ad hoc or theoretically unfocused explanations for the generally low level of cooperation in Central Asia are the presence of "local rivalries"11 and Russia's interest in preventing regional unity. ${ }^{12}$ Moreover, some believe that these five states do not wish to compromise their sovereignty during their long process of nation-building. ${ }^{13}$ Virtually absent from this scholarship on Central Asia are analyses that employ medium-N, crosscase comparisons in hopes of isolating generalizable causal mechanisms. The classic integration literature and the more recent scholarship of comparative regionalism ${ }^{14}$ remain largely untapped. Using Central Asia as a case in point, this author takes such research seriously. Ultimately, the analysis presented in this article is intended to contribute to a general understanding of regionalism and its limits beyond established democracies. ${ }^{15}$ The focus here is on security regionalism, which has barely been covered with regard to this region.

9 E.g., Zhenis Kembayev, Legal Aspects of the Regional Integration Processes in the Post-Soviet Area (Berlin: Springer, 2009); Richard Pomfret, The Central Asian Economies in the Twenty-First Century: Paving a New Silk Road (Princeton, NJ: Princeton University Press, 2019); Erika Weinthal, State Making and Environmental Cooperation: Linking Domestic and International Politics in Central Asia (Cambridge, MA: MIT Press, 2002).

10 E.g., Roy Allison, "Regionalism, Regional Structures and Security Management in Central Asia," International Affairs 8o, no. 3 (2004): 463-83; Elena Symonchuk, Regionaler Sicherheitskomplex Zentralasien: Analyse der innerstaatlichen und intra-regionalen Sicherheitsdynamiken (Wiesbaden: Springer vs, 2016).

11 Martin C. Spechler, "Regional Cooperation in Central Asia," Problems of Post-Communism 49, no. 6 (2002): 42-47.

12 Paul Kubicek, "Regionalism, Nationalism and Realpolitik in Central Asia," Europe-Asia Studies 49, no. 4 (1997): 637-55.

13 Ajay Patnaik, "Regionalism and Regional Cooperation in Central Asia," International Studies 56, no. 2/3 (2019): 147-62.

14 Walter Mattli, The Logic of Regional Integration: Europe and Beyond (Cambridge: Cambridge University Press, 1999); Tanja A. Börzel and Thomas Risse, "Introduction," in The Oxford Handbook of Comparative Regionalism, ed. Tanya A. Börzel and Thomas Risse (Oxford: Oxford University Press, 2016), 202-24.

15 Amitav Acharya, "Regionalism beyond EU-Centrism," in The Oxford Handbook of Comparative Regionalism, ed. Tanja A. Börzel and Thomas Risse (Oxford: Oxford University Press, 2016), 109-3o. 
The methodology used here is predominantly inductive. This article is based on extensive empirical observations, although these are embedded within the contractualist argument of rational institutionalism, which contends that states must share a common interest that can be achieved only through cooperation in order to build institutions such as regional organizations. ${ }^{16}$ Cooperation is defined as "mutual adjustment of the policy of country A to take into account the preferences and outcomes for country B." ${ }^{17}$ When understood thus, cooperation can be captured as a phenomenon of interaction that involves two or more states mutually helping one another to achieve their respective goals. In line with this conceptual frame, the next section asks what collective gains, if any, the five Central Asian states can possibly expect from security cooperation. The underlying logic is simple: If there are no potential gains, cooperation should not be expected. Consistent with this article's focus on cooperation among states (as opposed to nonstate actors), the concept of "regionalism" is used. ${ }^{18}$ It denotes "a primarily state-led process of building and sustaining formal regional institutions and organizations among at least three states."19

Given the article's inductive methodology, the explanatory findings remain tentative. To support their validity, future research will need to use a cross-case comparison to identify (a) which attributes about each case are unique and (b) what several of the cases-or all of them-have in common. This will make it possible to discern generalizable features that are likely to affect regionalism beyond the liberal democratic world. If these tasks can be accomplished simultaneously, the attributes unique to a given region can be identified.

16 Robert O. Keohane, After Hegemony: Cooperation and Discord in the World Political Economy (Princeton, NJ: Princeton University Press, 1984), 247-48.

17 Ibid., 53 .

18 There is a consensus in the literature that regionalism (implying a political will of identifiable actors and thus operating top-down) can be distinguished from regionalization as an analytical construct. Regionalization operates bottom-up, is more spontaneous, and points to an increasing cross-border flow of people, goods, or ideas, all driven by businesses, individuals, or civil-society actors.

19 Börzel and Risse, "Introduction," 7 (original emphasis removed). Note that other scholars add nonstate actors to their definition of regionalism (e.g., Amitav Acharya, "Comparative Regionalism: A Field Whose Time Has Come?,” The International Spectator 47, no. 1 [2012]:

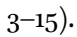


Invoking institutionalist insights, this section depicts the challenges to achieving security in Central Asia and asks why and to what extent these five states should cooperate with one another as a way of addressing these challenges. In institutionalist parlance, the question would be "Which collective gains could emerge from their cooperation when compared with noncooperation?"

Ideally, the spectrum of institutional arrangements in this policy field could range from fleeting, strictly intergovernmental cooperation within narrowly defined areas to much more comprehensive, highly integrated forms of cooperation that would involve supranational bodies with binding powers of decision-making and implementation, such as secretariats. An extreme example of the former type of arrangement would be the weak coordination of security strategies among three states that is entrenched in a loose formal arrangement and that lacks both detailed commitments and powers of enforcement. At the other end of the continuum would be a more exaggerated scenario involving a joint army consisting of soldiers from several states who are trained according to uniform standards and are supported by jointly conducted military research, arms planning and procurement. In this latter case, the underlying arrangement would be based on the principle of majority decision-making, whereby the joint army would be deployed if a simple majority of the governments involved so wished it. Leadership would then be assumed by a supranational general staff not bound by national directives.

The security problems currently encountered by the Central Asian states are predominantly transnational (i.e., cross-border) and involve at least one nonstate conflict party. In contrast, the danger of interstate violence has diminished significantly over the past two decades. ${ }^{20}$ For example, even though the massive violent conflict in southern Kyrgyzstan between ethnic Kyrgyz and the minority Uzbek population in 2010 resulted in many Uzbek victims, Uzbekistan did not intervene in its neighbor's territory. ${ }^{21}$ Recently, however, interstate conflicts have been superseded by complex, often linked transnational challenges that have potential or evident implications for regional security and

20 Conflicts among Uzbekistan, Kyrgyzstan, and Tajikistan were always the most intense. Tensions between Uzbekistan and Tajikistan were particularly explosive in the 199os due to Uzbekistan's intervention in the Tajik Civil War, its transport blockades against Tajikistan, border demarcation without prior consultation, and generally unclear borders. See Symonchuk, Regionaler Sicherheitskomplex Zentralasien, 111-20.

21 Robert Timm, "The Security Forces," in Central Asia in the Era of Sovereignty: The Return of Tamerlane?, ed. Daniel L. Burghart and Theresa Sabonis-Helf (Lanham, MD: Lexington Books, 2018), 367-89. 
include intergroup tensions, water scarcity, militant jihadism, and illegal drug trafficking. ${ }^{22}$ Some of these problems stem from, or are exacerbated by, developments in nearby volatile Afghanistan that threaten to spread to Central Asia, ${ }^{23}$ as has been particularly well illustrated in Tajikistan. ${ }^{24}$ An additional security challenge is the possible loss of domestic stability due to the erosion of authoritarian presidential systems, succession crises, or mismanagement, especially against the backdrop of protest movements and demands for participation by civil society actors. ${ }^{25}$ Finally, the dominance of the region's two neighboring superpowers, Russia and China, represents a latent danger.

Which cooperation strategies among the five Central Asian states would be appropriate to effectively counter the security challenges just outlined? To begin with, the military and economic superiority of Russia and China is so overpowering that, for example, the aggregate creation of a regional military alliance designed to provide regulated structures and an assistance clause to discourage external interventions (e.g., for land-grabbing, inciting unrest, or encouraging regime change) would hardly be promising. Compared with larger aggregations - such as the EU's security regime, which has several midlevel and nuclear powers - the five states simply lack the critical mass to act as a security collective with credible deterrent potential vis-à-vis their hegemonic neighbors. Hence, close security cooperation along these counterfactual lines is not very likely. Instead, unilateral strategies such as neutrality, bandwagoning (accommodating an overpowering hegemon), or balancing the two great powers through flexible foreign policy positioning appear to be more appropriate ways to deal with these potentially dangerous neighbors. As will be explained later, the two superpowers-especially Russia - are not merely security challenges, but can act as security providers for the Central Asian states.

In contrast, the transnational security challenges mentioned above evidently require cooperation-both among the five states and with outside actors. There are four key reasons for this:

22 Vivian Walker, "The Borderlands Paradox: Framing Central Asia's Current Economic and Social Challenges," in Central Asia in the Era of Sovereignty: The Return of Tamerlane?, ed. Daniel L. Burghart and Theresa Sabonis-Helf (Lanham, MD: Lexington Books, 2018), $5^{-26 .}$

23 Beate Eschment, Stabilität und Sicherheit in Zentralasien unter besonderer Berücksichtigung Afghanistans (Berlin: Friedrich-Ebert-Stiftung, 2009), 8-17.

24 Lena Jonson, Tajikistan in the New Central Asia: Geopolitics, Great Power Rivalry and Radical Islam (London: I.B. Tauris, 2006), 93-107.

25 Charles Buxton, The Struggle for Civil Society in Central Asia: Crisis and Transformation (Sterling, VA: Kumarian Press, 2011); Charles E. Ziegler, Civil Society and Politics in Central Asia (Lexington, KY: University Press of Kentucky, 2015). 
1. Transnational challenges (e.g., drug trafficking or illegal migration) are by definition cross-border phenomena that can easily shift from place to place. They require joint action because they affect neighboring statesif not now, then at some time in the future.

2. Transnational security challenges are complex and/or arise quickly. To prevent or mitigate such challenges, both these attributes require a substantial exchange of relevant information, national adjustments, and timely institutionalized coordination of national policies so that strategies can be deployed rapidly and effectively. Such strategies would obviously be less effective if the five states acted in isolation, lacking orchestration when adjustments are needed. This is because unilateral ad hoc actions would be neither timely nor appropriate once a given challenge arises.

3. The often extensive transnational challenges (e.g., terrorism) require vast resources that can be mobilized only when existing resources are somewhat pooled. In Central Asia, these resources are particularly scarce.

4. Unlike unilateral action, the multilateralism enshrined in institutionalized cooperation provides legitimacy, which autocratic regimes wish to gain, particularly when they face domestic unrest, but also when they are confronted internationally with alleged deviations from liberal democratic standards.

For these four key reasons, the five Central Asian states are facing some degree of functional pressure to opt for institutionalized cooperation in the security realm.

The following two sections depict the present low degree of regionalism by focusing on its intraregional and extraregional impacts, respectively. The penultimate section then attempts to provide explanations for this low degree, with the rational institutionalist argument taking center stage.

This section delineates attempts at institution-building for security cooperation among three or more of the five Central Asian states. If successful, this would obviously entail regionalism. Despite an abundance of relevant initiatives, institutions remain excessively weak, if not likely to be completely dissolved shortly after they are created. General attempts at cooperation will now be discussed according to several themes: military cooperation, coordination of foreign policy (including security), and the respective scopes of bilateral and multilateral agreements. Dissimilarities in terms of the foreign and security 
policy preferences of the five states will then be addressed, and the section will conclude with a more optimistic outlook that has prevailed since 2016, when Uzbek President Shavkat Mirziyoyev came to power.

After the dissolution of the Soviet Union, political elites in Central Asia made attempts at cooperating on security and military affairs without the participation of external actors. A considerable spirit of integration could be perceived that was significantly fanned by Kazakhstan as a way to offset ongoing bilateral tensions. ${ }^{26}$ In this regard, the president of Kazakhstan at the time, Nursultan Nazarbayev, had put forward European integration as a model. ${ }^{27} \mathrm{At}$ a summit meeting in Tashkent in January 1993, the five presidents decided to replace the Soviet label "Kazakhstan and the Middle Asian States" with the term "Central Asia," thus referring to their group of states as a distinct region. ${ }^{28}$ At the same meeting they also agreed to form a common market that would ensure uniform tax rates and coordinate investment and export policies. As a result of this initiative, Kazakhstan, Uzbekistan, and Kyrgyzstan signed the Treaty for the Establishment of an Integrated Economic Space in the first half of 1994. The Treaty led to the establishment of the Central Asian Union $(\mathrm{CAU}),{ }^{29}$ with the ultimate goal of creating a common Central Asian market. ${ }^{30}$

In 1994, these three CAU members also engaged in building security institutions. The Agreement on Military-Technical Cooperation was designed to provide for cooperation in the areas of procurement and military logistics and for duty-free trade in weapons technology, and it led to a degree of military cooperation among members of the CAU. By the end of 1995, the CAU Council of Defense Ministers had been established to coordinate joint exercises and defense efforts. ${ }^{31}$ In 1996 CAU members also signed the Treaty of Eternal Friendship, the most important goals of which were security policy

26 Dauren Akberdiyev, Die Diversifizierung internationaler sicherheitspolitischer Kooperation Kasachstans von der Unabhängigkeitserklärung bis zur Gegenwart (PhD diss., University of Hamburg, 2014), 45-52; Marlène Laruelle, "Kazakhstan's Dilemma on Eurasian and Central Asian Integration," in Central Asia in the Era of Sovereignty: The Return of Tamerlane?, ed. Daniel L. Burghart and Theresa Sabonis-Helf (Lanham, MD: Lexington Books, 2018), 395-413; Symonchuk, Regionaler Sicherheitskomplex Zentralasien, 46-48.

27 Assylzat Karabayeva, "Leaders, Ideas and Norm Diffusion in Central Asia and Beyond," Asian Journal of Comparative Politics, no. 6 (2019): 25-44.

28 Ibid., 1.

29 In 1998 the CAU was renamed the Central Asian Economic Union (CAEU) and Tajikistan joined in the same year. In 2002 the CAEU was dissolved or transferred to other international organizations.

30 Kembayev, Legal Aspects of the Regional Integration Processes in the Post-Soviet Area, 179-82.

$31 \quad$ This Council was dissolved in 2001. 
coordination and comprehensive cooperation, including the clarification of border issues. ${ }^{32}$ In addition to the integration of the Central Asian states, Kazakhstan's Nazarbayev demanded that supranational institutions be created more generally within the Commonwealth of Independent States (CIS) and a potential "Euro-Asian Union." In this context, he argued that "by giving up part of sovereignty, a state can get even more sovereignty."33 In 1999 all but Turkmenistan negotiated an agreement to establish a Central Asian regional security system, ${ }^{34}$ but this never materialized. Over time, it was understood that such initiatives often represented merely "pseudo-regionalism,"35 with no tangible results.

Although a joint Central Asian army could have been built based in part on the experience during the Soviet era via cooperation in the Central Asian military district, ${ }^{36}$ such an army was never created. The initial idea voiced by Russia $^{37}$ of forming joint armed forces with a regional command structure in Central Asia within the cIs (which was founded in December 1991) would have made the development of national armed forces unnecessary. This proposal was met with a positive response in some Central Asian states, such as Kyrgyzstan. ${ }^{38}$ However, an overarching consensus in this direction never evolved. In addition to conflict prevention and conflict settlement operations such as those extant during the Tajik Civil War, which provided cover for de

32 Allison, "Regionalism, Regional Structures and Security Management in Central Asia," 473; Rustam Burnashev, "Regional Security in Central Asia: Military Aspects," in Central Asia: A Gathering Storm?, ed. Boris Rumer (Armonk, NY: M.E. Sharpe, 2002), 114-65, 140-41; B.Zh. Somzhurek, A.M. Yessengaliyeva, Zh.M. Medeubayeva and B.K. Makangalib, "Central Asia and Regional Security," Communist and Post-Communist Studies 51, no. 2 (2018): 161-71, here $164-65$.

33 Karabayeva, "Leaders, Ideas and Norm Diffusion in Central Asia and Beyond," 8.

34 Allison, "Regionalism, Regional Structures and Security Management in Central Asia," 474; Rustam Burnashev and Irina Chernykh, "Conditions for Securitization of International Terrorism in Central Asia," in Connections: The Quarterly Journal 4, no. 1 (2005): 131-42, $136-37$.

35 Roy Allison, "Blockaden und Anreize: Autoritarismus und Regionale Kooperation," in Sonderheft Machtmosaik Zentralasien: Traditionen, Restriktionen, Aspirationen, ed. Manfred Sapper, Volker Weichsel and Andrea Huterer, Osteuropa 57, no. 8/9 (2007): 25775,263 .

36 Somzhurek et al., "Central Asia and Regional Security," 165 .

37 Allison, "Regionalism, Regional Structures and Security Management in Central Asia," 470,472 .

38 Marina Tsoi, Die Außenpolitik der Kirgisischen Republikvon 1991 bis 2007: Eine Analyse unter besonderer Berücksichtigung der Kleinstaatentheorie (PhD diss., Katholische Universität Eichstätt-Ingolstadt, 2008), 8o. 
facto unilateral Russian military actions, ${ }^{39}$ the cIs — short of a joint armywas eventually active in building new armed forces in several of the five Central Asian states. An example of the rapid demise of an integration initiative was the Central Asian Peace Battalion (CEnTrazbat) initiated by Kazakhstan in late 1994. The focus of CENTRAZBAT was to carry out possible peacekeeping operations in Central Asia while being managed by the United Nations (UN). Under the UN aegis, this initiative was developed by Kazakhstan, Kyrgyzstan, and Uzbekistan in October 1997 but lasted less than three years. Beyond some joint military exercises, no deployment took place. Since the dissolution of CENTRAZBAT, Kazakhstan has been attempting to unilaterally fulfill the program's originally envisioned tasks, namely through the Kazakh Peace Keeping Battalion (KazBat). ${ }^{40}$

At the highest political level, the five states share an informal consultation forum. Since the early 199os, Central Asian summits attended by heads of state have been held at which security issues were also discussed. ${ }^{41}$ Nevertheless, both the degree of precision and the implementation of joint agreements have remained largely insufficient. In addition, the meetings were not held regularly until a few years ago, so it was not even possible to speak of an informally institutionalized network with at least regular meetings, as exemplified by the $\mathrm{G}_{7}$ or G2O summits. In 2017, new Uzbek President Mirziyoyev suggested that the five presidents hold regular meetings. Since 2018, meetings have been planned to be held annually as "Central Asian Consultative Summits."42 Although the Central Asian heads of state meet on other occasions every year (e.g., summits of the Shanghai Cooperation Organization [sco] and the Collective Security Treaty Organization [CSTO]), all five are rarely represented in unison at these other meetings. ${ }^{43}$ In addition, representatives from extraregional countries, including heavyweights such as Russia and China, are usually in attendance, resulting in strongly asymmetrical intraorganizational power relations. These extraregional impacts are aggravated even more by the strongly intergovernmental modes of decision-making practiced by these organizations, which

39 Lena Jonson and Clive Archer, Peacekeeping and the Role of Russia in Eurasia (Boulder, CO: Westview Press, 1996).

40 On actual and potential deployments of KazBat, see Victoria Panfilova, "Kazbat Is Ready for Peacemaking Mission," Vestnik Kavkaza, June 22, 2015, http://vestnikkavkaza.net/ analysis/Kazbat-is-ready-for-peacemaking-mission.html.

41 Somzhurek et al., "Central Asia and Regional Security," 165-66.

42 The next summit, initially scheduled for March 2019 in Tashkent, was postponed to December 2020. In 2020, the third Consultative Meeting is scheduled to be held in Bishkek.

43 For example, Turkmenistan is not a member of the sco or the csTo, and Uzbekistan is not a member of the csto. 
favor largely unrestrained state power. The scope of negotiations is also broader and less specifically tailored to Central Asia. So far, no regional consultation meetings on security issues have taken place below the presidential level. Eschment has characterized the declaratory, always flowery, but rarely substantial regional cooperation efforts of the five states as "too many, too high and having goals that are too abstract." 44

The Central Asian states have signed a number of agreements with one another that do not include extraregional actors. Treaties that have security implications deal primarily with border issues; with strategies to prevent drug trafficking, terrorism, and crime; and with military/technical cooperation. Nevertheless, most of them are merely bilateral and are often concluded within the context of larger institutional arrangements, such as the sco, the СSTO, and the CIS ${ }^{45}$ and therefore fall short of the concept of regionalism as it is understood here. Multilateral security agreements that fit this definition of regionalism (i.e., those involving three or more states) are considerably scarcer. Examples are the 1994 intergovernmental agreement signed by Kazakhstan, Kyrgyzstan, and Uzbekistan on military cooperation and the 2011 agreement signed by Kazakhstan, Kyrgyzstan, and Tajikistan on civil protection. ${ }^{46}$ The Semei Treaty (Central Asian Nuclear-Weapon-Free Zone [CANWFZ] Treaty), which came into force in 2009, is the only security treaty that involves all five Central Asian states and includes no extraregional contractual parties, ${ }^{47}$ although it reflects the status quo rather than demanding ambitious benchmarks. It prohibits the testing, stationing, possession, and manufacturing of nuclear weapons in Central Asia.

Along with the aforementioned integration rhetoric, relations among the five states have also been marked by mistrust. ${ }^{48}$ Moreover, their individual foreign and security policy preferences have increasingly diverged. Tajikistan and Turkmenistan did not join the CAU in the first place. At least until 1997, the Tajik government under President Emomali Rahmon was barely able to pursue foreign policy against the backdrop of the civil war and numerous political

44 Eschment, Stabilität und Sicherheit in Zentralasien, 21 (author's translation).

45 Symonchuk, Regionaler Sicherheitskomplex Zentralasien, 107-44.

46 Ibid., 130, 125 .

47 See "Central Asia Nuclear-Weapon-Free-Zone," Nuclear Threat Initiative, September 17, 2020, https://www.nti.org/learn/treaties-and-regimes/central-asia-nuclear-weapon -free-zone-canwz.

48 Allison, "Regionalism, Regional Structures and Security Management in Central Asia," 473-74; Nicole J. Jackson, "Sicherheitskooperation in Zentralasien: Der Kampf gegen Drogenhandel und Terrorismus," in Sonderheft Machtmosaik Zentralasien: Traditionen, Restriktionen, Aspirationen, ed. Manfred Sapper, Volker Weichsel and Andrea Huterer, Osteuropa 57, no. 8/9 (2007): 357-68. 
murders and kidnappings. ${ }^{49}$ Turkmenistan opted for an isolationist policy of "permanent neutrality," largely closing itself off from regional initiatives, which to this day makes this state the "odd man out."50 There was also no consensus among the other four states regarding the security integration offered by external actors. For example, unlike Kazakhstan and Kyrgyzstan, Uzbekistan, with its strongly unilateral foreign and security policies, refused to have its borders guarded by Russian-dominated cis troops. ${ }^{51}$ One strategic imperative of Tashkent's foreign policy during the Karimov period (1989-2016) was to remain equidistant from all global power centers. This implied that the shape of potential regional cooperation would continue to be contested between Kazakhstan and Uzbekistan, the two preeminent Central Asian states in terms of wealth and population, respectively. While Nazarbayev made a plea for supranational arrangements, Uzbek President Karimov consistently opposed compromising the country's sovereignty greater extent and therefore prioritized the creation of a web of bilateral agreements. ${ }^{52}$

Cooperation efforts have increased since 2016 in view of the new, more cooperative Uzbek leadership after Karimov's death, although Uzbekistan's legacy of bilateralism endures to a degree. When new president Mirziyoyev came to power in 2016, relations with neighboring Central Asian states improved, although substantial results are still difficult to determine, particularly in the field of security. An example of new cooperative stimuli with potentially more substantive results is the key conference that took place in Samarkand, Uzbekistan, in November 2017. Although it was convened under the aegis of the UN, it arose from Mirziyoyev's aforementioned initiative for a regional consultation mechanism to solve common problems. It was attended not only by the five Central Asian states, but also by representatives from all the major international organizations that are active in the region. Noteworthy moves that reflect the new Uzbek openness include the lifting of objections to the Kambar-Ata 1 dam (in Kyrgyzstan) and the Rogun dam (in Tajikistan), somewhat defusing the "water and conflict" nexus. Around the time Mirziyoyev assumed power, two bilateral strategic partnership agreements came into force, one with Kazakhstan (2013) and one with Turkmenistan (2017). These agreements were still largely in line with Uzbekistan's preference for bilateralism and have thus far led to increased cooperation, including joint infrastructure projects and

49 Jonson, Tajikistan in the New Central Asia, 40-48.

50 Timm, "The Security Forces," $379-81$.

51 Thomas Koszinowski and Hanspeter Mattes, "Neue Allianzen und Gegensätze in Zentralasien und Kaukasien," in Nahost Jahrbuch 1997, ed. Deutsches Orient-Institut (Wiesbaden: vs Verlag für Sozialwissenschaften), 221-26, 225.

$5^{2}$ Karabayeva, "Leaders, Ideas and Norm Diffusion in Central Asia and Beyond," 5-7, 9. 
select border openings. ${ }^{53}$ Yet given that they are bilateral instead of multilateral, they fall far short of the strict understanding of the term "regionalism." In principle, the agreements could be upgraded to a broader network of strategic bilateral relations-perhaps ultimately even culminating in a truly Central Asian regional organization.

\section{$5 \quad$ External Actors Nurturing Regionalism}

This section addresses the impact of extraregional actors (both state and nonstate), including Russia and China, on the building and sustaining of regional cooperation. A crucial caveat is that extraregional entities by definition do not usually foster "regionalism," a concept for which regional institutions are one defining criterion. Nonetheless, they may function as catalysts and may encourage multilateral action that would not otherwise have occurred. This section focuses on the creation of new armies that have come to rely largely on external aid, as well as the functions of a number of security organizations that involve external actors. The discussion also includes cases of the novel or increased involvement of external actors since September 11, 2001.

In the early 1990s, immediately after they gained independence, ${ }^{54}$ the five Central Asian states still had no full-fledged, autonomous armed forces and special services. ${ }^{55}$ What is more, the civil war in Tajikistan raged from May 1992 to June 1997. Also, interstate border disputes were more frequent than they are at present, creating a considerable risk that interstate conflicts would escalate. The five states attempted to meet the challenges outlined above through independent efforts at regional cooperation, but overall, they have relied largely on institutional structures nurtured by extraregional actors.

In order to build up professional armed forces and allow for temporary protection, several of the non-Russian post-Soviet states made use of the Russian-dominated Collective Security Treaty (CST). ${ }^{56}$ Founded in 1992 by

53 Umida Hashimova, "In Central Asia, Strategic Partnerships Growing Ascendant," The Jamestown Foundation, Eurasia Daily Monitor 14, no. 59, May 3, 2017, https://jamestown .org/program/central-asia-strategic-partnerships-growing-ascendant.

54 Olivier Roy, The New Central Asia: The Creation of Nations (London: I.B. Tauris, 20oo), 195-98.

55 Burnashev, "Regional Security in Central Asia," 141-43; Hooman Peimani, Regional Security and the Future of Central Asia: The Competition of Iran, Turkey and Russia (Westport, CT: Praeger, 1998), 69-70.

56 Marina Tsoi, Die Außenpolitik der Kirgisischen Republik, 79-83; Collective Security Treaty Organization, “Basic Facts," n.d., http://www.odkb.gov.ru/start/index_aengl.htm. 
Russia, Uzbekistan, Kazakhstan, Kyrgyzstan, Tajikistan, and Armenia, ${ }^{57}$ the CST (which later developed into the CSTO) became a key instrument for common defense and the creation of new armies for non-Russian members. To this end, individual units and institutions of the former Soviet Army were placed under new jurisdiction. Mostly on a bilateral basis, Russia provided selective support for the development of armed forces in other member states and of legal frameworks for this purpose. Although the CST provided a platform for bilateral projects, it barely evolved in the direction of a multilateral framework. ${ }^{58}$ In addition to its military-technical function, the CST - contrary to its name-focuses not on collective security (i.e., for the purpose of internally preventing violent conflict) but on collective defense. ${ }^{59}$ An assistance clause in Article 4 of the CST, which is comparable to NATO's Article 5, allows for "necessary-also military—assistance."

After the collapse of the Soviet Union and the independence of its successor states in 1991, tensions in and around Central Asia resulted from the increase in unclear borders. In 1996, to help resolve these tensions, Russia and China along with Kazakhstan, Kyrgyzstan and Tajikistan (which all share borders with China) signed a multilateral agreement known as the Shanghai Agreement on Confidence Building in the Military Field in the Border Area. In addition to this multilateral framework there were numerous bilateral agreements, which is not surprising given the border problems. In 1997 the signatories to the Shanghai Agreement also concluded the Agreement on Mutual Reduction of Military Forces in the Border Areas. ${ }^{60}$ The Shanghai Five Group, the forerunner of the Shanghai Cooperation Organization (SCO), was founded at the same time as this agreement was signed. Among other things, the Group frequently organized summit meetings and issued joint declarations, and defense ministers met regularly to coordinate security strategies. The documents also provide

57 In 1993 Azerbaijan, Georgia and Belarus joined as full members.

$5^{8}$ Kirill Golub and Yuri Golub, "Collective Security Treaty Organization: Origins of the Multidimensional Mandate and Modern Means for Its Implementation," International Organisations Research Journal 13, no. 1 (2018): 193-203, 193-97.

59 In contrast to collective defense alliances, which are aimed at countering external threats, systems of collective security are inward-looking-that is, they aim to secure peace among the member states themselves. The prime example of a system of collective security is the United Nations. This description also tends to apply to the Organization for Security and Co-operation in Europe (OSCE), even though it has no means of employing military coercion. At the end of the 200os, the СSTO, which is basically a collective defense alliance, took on certain features of a system of collective security by way of establishing Joint Peacekeeping Forces meant to manage conflicts within the CSTO member territory (see below).

6o Burnashev, "Regional Security in Central Asia," 136. 
for disarmament measures. With Uzbekistan's accession to the Shanghai Five and the signing of the Declaration establishing the SCO on June 15, 2001, the Shanghai Group became the sco. ${ }^{61}$ With the exception of Turkmenistan, the sco initially comprised all the Central Asian states, but also two hegemonic powers that have been instrumental in shaping sco matters. ${ }^{62}$ Therefore, strictly speaking, associated activities do not exemplify regionalism in Central Asia. Problem-solving within the sco has focused on border disputes and arms control, although its spectrum of activities has increased over time to include such tasks as countering terrorism and drug trafficking. ${ }^{63}$

Uzbekistan was a founding member of the CST, the forerunner of the csто. In 1999, however, it did not extend the treaty and thus sealed its withdrawal. It joined the CSTO in 2006 but then decided to withdraw again in 2012, apparently because the organization had developed capabilities for inward-directed operations. ${ }^{64}$

One set of forces for such operations had already been created in 2009: the Joint Peacekeeping Forces, consisting of about 3,60o military, civilian, and police personnel to manage conflicts within the сsто area. In addition, the Rapid Reaction Forces came into being, consisting of about 17,00o soldiers and other security personnel. The Rapid Reaction Forces were established primarily to combat terrorist attacks on Central Asia that originated in Afghanistan. So far, both these forces have only carried out exercises; however, with Russian resources, they have become considerably more professional over time. ${ }^{65} \mathrm{In}$ addition to its evolving collective security function and obligation to provide assistance against external attacks ${ }^{66}$ (functions established by the CST that continue to be features of the CsTO), the organization still counts militarytechnical cooperation among its core functions. Crucially, however, such cooperation is largely organized bilaterally between Russia and other individual

61 On June 7, 2002, a charter was signed in St. Petersburg that defines the objectives, principles, structure and actions of the sco.

62 At the June 2017 summit in Astana (now Nursultan), India and Pakistan were also admitted as members.

63 Marc Lanteigne, "Russia, China and the Shanghai Cooperation Organization: Diverging Security Interests and the 'Crimea Effect,'” in Russia's Turn to the East: Global Reordering, ed. Heldge Blakkisrud and Elana Wilson Rowe (Cham: Palgrave Macmillan, 2018), 119-38, $122-27$.

64 Symonchuk, Regionaler Sicherheitskomplex Zentralasien, 152-56; Timm, "The Security Forces," 377 .

65 Margarete Klein, Russlands Militärpolitik im postsowjetischen Raum: Ziele, Instrumente und Perspektiven (Berlin: Stiftung Wissenschaft und Politik, 2018), 32-35.

66 The csтo has existed as such since September 2003 but remains based on the still existing CST. 
members. In contrast, relations among non-Russian members of the CSTOincluding the five Central Asian states-are much weaker within this organization's framework. ${ }^{67}$ As a consequence, collaboration remains mostly bilateral (as opposed to multilateral) and extends beyond the region. Thus, strictly speaking, this does not qualify as regionalism, which implies geographical limitation.

After September 11, 2001, not only Afghanistan but also Central Asia became the focus of international counterterrorism efforts and intensified security engagements. ${ }^{68}$ As early as 1992, the United Nations Security Council (UNSC) aimed to prevent Afghanistan's negative developments from spreading to Central Asia. ${ }^{69}$ At the end of the decade, the development of measures to combat terrorism and drug trafficking gained momentum within the framework of the UNSC. This resulted primarily from the rise of radical jihadism in the areas bordering Afghanistan and in the North Caucasus. Especially toward the end of the 199os, Islamist groups appeared and also engaged in violent clashes with the often (still) unprofessional national armed forces. ${ }^{70}$ The CSTO, created in 2003, was concentrated even more strongly to fight against transnational threats. Since then, drug supervisory authorities, the police, border guards, customs and financial investigation authorities, and the security services of CSTO members have been working together even more closely to prevent drug trafficking, especially along the border with Afghanistan. ${ }^{71}$ In 2004 the sco developed the Regional Counter-Terrorism Centre in Tashkent, which enables the exchange of intelligence and the coordination of joint measures in this area. The сsто and sco now also conduct antiterror and antidrug operations. ${ }^{72}$ To maintain the autocratic status quo, such measures are also used by Central

67 Nikolai Bordjuscha, "Die Organisation des Vertrags über kollektive Sicherheit-ein kurzer Überblick," in OSZE-Jahrbuch 2010, ed. Institut für Friedensforschung und Sicherheitspolitik an der Universität Hamburg (Baden-Baden: Nomos, 2011), 379-91, 38284; Klein, Russlands Militärpolitik im postsowjetischen Raum, 34; Symonchuk, Regionaler Sicherheitskomplex Zentralasien, 154.

68 Jackson, "Sicherheitskooperation in Zentralasien," 366-67.

69 Burnashev, "Regional Security in Central Asia," 134.

70 Uwe Halbach, Zentralasien im Umfeld des globalen Jihadismus (Berlin: Stiftung Wissenschaft und Politik, 2017), 3-4; Jackson, "Sicherheitskooperation in Zentralasien," 36o. One example is the Islamic Movement of Uzbekistan, which cooperated with the Taliban and, in 1999 and 200o, attempted to advance from Tajikistan via Kyrgyzstan into Uzbek territory.

71 Bordjuscha, "Die Organisation des Vertrags," 385-87.

72 Jackson, "Sicherheitskooperation in Zentralasien," 364-66; Symonchuk, Regionaler Sicherheitskomplex Zentralasien, 160-65. 
Asian authoritarian leaders as instruments of repression against the participation and emancipation efforts of the opposition and civil society. ${ }^{73}$

The events of September 11, 2001, also encouraged actors farther afield to increase their presence or to start providing external governance in Central Asia. For the five states, this opened up the possibility of alleviating their strong dependence on Russia. Examples of such actors include India, Turkey, Iran, and the U.S., with its $\mathrm{C}_{5}+1$ format (a diplomatic consultation platform). What is more, other international organizations have become increasingly active. For example, since 2002, the EU's Program on Border Management in Central Asia (вомса) has advanced to become the central player in this field of action. In 2005 the OSCE developed the Border Security and Management Concept and established the Border Management Staff College in Dushanbe within the framework of its office in Tajikistan. Strongly motivated by NATO's International Security Assistance Force (ISAF) operation in Afghanistan, which began in 2003, NATO-Central Asia relations have deepened in the areas of military reform and logistics, among other things. ${ }^{74}$ Uzbekistan and Kazakhstan cooperated closely with NATO and Turkey, whereas Tajikistan and Uzbekistan collaborated closely with India. ${ }^{75}$ In terms of the value of arms exports to Central Asia, Russia was the only significant arms exporter (particularly to Kazakhstan and Tajikistan) until 1998. Since 1999, Turkey, Ukraine, and the United States have also provided arms to the region (particularly to Kazakhstan and Turkmenistan). In 2011, arms exporters from the EU, including Germany, Italy, Spain, France, and the Netherlands, began to appear on the market, with the largest shares of their arms going to Kazakhstan and Turkmenistan and, since 2015, to Uzbekistan as well. ${ }^{76}$ These novel or intensified contacts and the external support have somewhat stifled institutions

73 Allison, "Blockaden und Anreize," 264; Burnashev and Chernykh, "Conditions for Securitization of International Terrorism in Central Asia”; Anna Kreikemeyer, "Herrschaft statt Sicherheit: Die Organisation des Vertrags für Kollektive Sicherheit," Osteuropa 62, no. 5 (2012): 81-91.

74 Uguloy Mukhtorova, Central Asia and NATO Against a Backdrop of Changing Geopolitical Realities (Rome: NATo Defense College, 2018).

75 Somzhurek et al., "Central Asia and Regional Security," 166.

76 Central Asia Arms Flow Map, Oxus Society for Central Asian Affairs (based on data from the Stockholm International Peace Research Institute Military Expenditure Database, supplemented by government documents, arms export reports of the European Union, the annual Military Balance reports of the International Institute for Strategic Studies and local media reports). See https://oxussociety.org/viz/arms-flows. 
that are dominated by Russia and China. ${ }^{77}$ Nonetheless, the five states' related bilateral security agreements with Russia, underpinned by the SCO and CSTO, remain most pronounced.

Despite its continued preeminence, Russia's roles in Central Asia have changed somewhat over time in terms of strategy. During the 199os, when it helped build new armed forces, it was an actor with no strategic vision. During the 20oos under President Vladimir Putin, Russia gestured toward greater international magnitude and advocated notions of a "multipolar world." For Central Asia this meant a more proactive policy to serve these purposes. Nevertheless, during the 20oos, Russia also met with increasing competition from other extraregional actors, as mentioned in the previous section. After a period of pragmatic U.S.-Russian cooperation for the purpose of containing terrorism after September 11, 2001, relations turned increasingly sour. Around 2005 , as the wave of democratically motivated revolutions unfolded in Georgia, Ukraine, and Kyrgyzstan, Russia sought to contain the U.S. with its bases on Central Asian soil. By way of the aforementioned institutional structures under Russian leadership, Moscow bolstered its security and military profile in the region throughout the 2000s. ${ }^{78}$ This state of affairs did not change profoundly between 2010 and 2020 . Currently, bilateral security relations with Russia remain particularly pronounced in Kyrgyzstan and Tajikistan, while they are less so with Kazakhstan, Uzbekistan, and Turkmenistan. ${ }^{79}$ Chiefly since the middle of the 2010s, Russia has displayed a relative neglect of Central Asia. This change is due in particular to Russia's energy-sapping interventions and belligerence elsewhere (Crimea, Eastern Ukraine, Syria), but also to the lack of both violent conflict and regime changes toward liberal democracy in Central Asia.

China, particularly via its sco engagements, can likewise be considered a key extraregional security provider, albeit less so than Russia. Its strengths lie in the economic sphere, where an energy-hungry and export-driven China must be considered the single greatest competitor to Moscow in Central Asia

77 Allison, "Regionalism, Regional Structures and Security Management in Central Asia," 468-69, 480; Rumer, "The Search for Stability in Central Asia," 57-6o.

78 Zhanibek Arynov and Dina Sharipova, "Russland in Zentralasien," in Die politischen Systeme Zentralasiens: Interner Wandel, externe Akteure, regionale Kooperation, ed. Jakob Lempp, Sebastian Mayer and Alexander Brand (Wiesbaden: Springer, 2020), 223-41, 228-30; Sally Cummings, "Happier Bedfellows? Russia and Central Asia under Putin," Asian Affairs 32, no. 2 (2001): 142-52; Dina Spechler and Martin Spechler, Putin and His Neighbors: Russia's Policies Toward Eurasia (London: Lexington Books, 2019).

Klein, Russlands Militärpolitik im postsowjetischen Raum, 29-30. 
(and elsewhere). Yet these ambitions also have politico-strategic and security implications. China's vastly resourced Belt and Road Initiative (BRI), launched in 2013, is shaping transport and trade infrastructure such as pipelines, railroads, highways, and power plants in Central Asia and beyond-and not always in line with Russian preferences. Over time, China has managed to break Russian companies' monopoly on transporting oil and gas by pipeline out of the Caspian region, and its exports to Central Asia are gradually growing. Moreover, in 2014, Beijing started exporting arms to the region, predominantly to Kazakhstan, Turkmenistan, and Uzbekistan (with an aggregated $\$ 328$, \$234, and $\$ 122$ million, respectively, from 2014 through 2019). ${ }^{80}$ As early as the 199os, there were fears in Beijing that the newly independent neighbors Kazakhstan and Kyrgyzstan would sympathize with the Uyghur separatists in the Xinjiang province in northwest China. Beijing therefore linked economic backing for the two states to their explicit pledge to refrain from supporting these separatists. ${ }^{81}$ Associated Chinese preferences were underpinned by the abovementioned institutional formats, which ultimately led to the formation of the sco. Within the framework of bodies such as the Regional Counter-Terrorism Centre, the sco also nurtures cooperation within Central Asia, albeit involving external powers.

In conclusion, the aforementioned extraregional state and nonstate actors have contributed to increased security cooperation not only bilaterally, but in part multilaterally as well: there has been an increase in information exchange, intelligence consultation, policy coordination, and joint action on security matters within Central Asia. Yet once again, these developments foster intraregional cooperation only to a certain extent. Institutional structures that reach beyond Central Asia cannot be understood as regionalism in the strict sense.

\section{Why Is There So Little Security Regionalism?}

Is the low level of security regionalism in Central Asia puzzling? In other words, should we wonder why there is so little cooperation against the backdrop of theoretical expectations? To address this question, a number of causal arguments can be put forward. Some of these relate to regime type. In addition, because their resources are limited, it would appear rational for the five states

\footnotetext{
80 Central Asia Arms Flow Map, Oxus Society for Central Asian Affairs.

81 Graham E. Fuller and S. Frederick Starr, The Xinjiang Problem (Washington, DC: John Hopkins School University, Central Asia-Caucasus Institute, 2004).
} 
to rely largely on external cooperation partners instead of being self-organized. Finally, the "hegemonic stability" argument is discussed. The relative weight and interplay of these possible causal mechanisms are still poorly understood, so they should be considered preliminary rather than definite.

One initial caveat is that security is generally a sovereignty-sensitive policy field in which state autonomy is a valuable asset and is not easily compromised. Nonetheless, despite reluctance in quite a few regions, we can observe that building security institutions is not categorically impossible. The literature on integration and security regionalism reveals that there is considerable formal cooperation in several regions, including the EU.

Variation might be explained by arguing that merely autocratic states are profoundly less eager to cooperate. The underlying logic is that deep cooperation is always entangling and in particular undermines the potential for an autocratic regime's survival. As institutional theory emphasizes, cooperation not only comes with benefits but also requires costly adjustments. Indeed, the case of Central Asia shows that Uzbekistan and Turkmenistan in particular have long been fundamentally unenthusiastic in this regard, given their foreign policy doctrines of "self-reliance" and "positive neutrality." However, Uzbekistan's foreign policy U-turn toward more cooperation in 2016 (despite still having largely arbitrary political structures) does not align well with the "autocratic hesitance" argument. What is more, Kazakhstan and Kyrgyzstan displayed strong preferences for security integration from the outset, including the creation of joint troops, thus implying an extensive cession of sovereignty. Hence, preferences are more varied in the midst of autocracies than the "autocratic hesitance" argument suggests. Fractures among the five Central Asian states, rather than an unwillingness across all five, have evidently obstructed greater security cooperation in this region. Furthermore, other regional security organizations that comprise autocracies have made immense institutional progress, such as the African Union with its paradigm shift from "noninterference" to "non-indifference." The "protective integration" argument holds that autocracies are fundamentally more willing to cooperate with one another in defensive institutional frameworks (such as the CSTO and SCO) as opposed to the OSCE. Indeed, autocracies try to balance organizations with liberal agendas. Nevertheless, they do not cancel their memberships of the OSCE, and the institutional depth of autocratic organizations remains poor, with virtually no power ceded to international bodies. Finally, the "illiberal solidarism" argument ${ }^{82}$ cannot logically account for the absence of large-scale regionalism 
because the latter's exclusivity precisely permits tailor-made institutions that can be shielded from democratic interference.

The institutionalist cooperative gains argument mentioned at the outset raises the following associated question: Which advantages would a significantly greater degree of interstate cooperation actually accord to the five Central Asian states compared with the low degree described above? Their bilateral cooperation, particularly with Russia, is most advantageous for both sides in each dyad. The five states receive security guarantees, armaments, and assistance in professionalizing their armed forces (often below market prices) - services they would never be able to provide independently, even with highly integrated cooperation and considerable expenditures, given their tiny armed forces. ${ }^{83}$ Russia, in turn, receives residence rights for military bases from all Central Asian сsто members. Moscow can also use institutionalized exclusion clauses and rights of objection to keep perceived rivals at a distance. In addition, the CsTo represents a key political instrument that allows Moscow to harmonize foreign and security policy positions in the treaty area and to mask, or positively reinterpret, its warmongering elsewhere. Cooperation logics with other external actors might be less straightforward. However, they also involve benefits, such as the EU or NATO wishing to tackle security problems at the source, thus preventing them from slipping over into their member-states' territory. ${ }^{84}$ The crucial point is that accepting offers from well-off external actors to achieve security, rather than relying on self-organization, is a rational move by the five states, since self-organization would be much more costly.

A final explanatory pathway pertains to regional leadership. With a view not only to the global level but also in large part to comparative regionalism, international cooperation can be significantly facilitated by a dominant state willing to lead. Likewise, this thesis implies that there is a social relationship with followers who are ready to accept this leadership. In the words of the progenitor of this school of thought, "there has to be a stabilizer, one stabilizer." 55 The underlying logic is that a wealthy and powerful hegemon is in a position to offer incentives or side payments for costly adjustments to cooperation

83 Klein, Russlands Militärpolitik im postsowjetischen Raum, 13-24; Timm, "The Security Forces," 30-31.

84 It is true that several external actors have value-driven elements in their agendas that cannot be captured by rational logic, although rational logic is usually flexible in incorporating sociological institutionalist insights to some extent.

85 Charles P. Kindleberger, The World in Depression, 1929-1939: Revised and Enlarged Edition (Berkeley and Los Angeles, CA: University of California Press, 1986 [1973]), 304 (emphasis in original). 
and punish those who defect from joint agreements. If this thesis is correct, it could in part explain the low degree of security cooperation in Central Asia. Kazakhstan and Uzbekistan, two of the five states, are plausible candidates for regional leadership, but neither is likely to accept the leadership of the other. ${ }^{86}$ Kazakhstan's outstanding economic strength, as well as its considerable population size and numerous regional integration initiatives, combined with a claim to leadership, speak in its favor. Uzbekistan's status as by far the most populous country in Central Asia speaks for itself. Nonetheless, under the presidency of Islam Karimov and his ideology of "national independence," Uzbekistan did not develop its own impulses for integration and cut itself off from external ones. Since 2016, the new foreign policy openness espoused by Mirziyoyev has been proving to be a double-edged sword. On the one hand, the former dissenter is now "back on the cooperation track;" on the other, the new Uzbek openness to cooperation tends to increase competition with Kazakhstan with regard to regional leadership. Kazakh decision-makers are exhibiting some irritation at the Uzbek president's signs of Central Asian leadership. ${ }^{87}$ In view of this, the likelihood that leadership by one regional actor will be accepted as a (possible) prerequisite for extensive regionalism might be declining with Mirziyoyev's tenure.

Nevertheless, the argument that only one single hegemon (supported by all other states) will allow for significant cooperation has not gone uncontested. With regard to the global level, empirically grounded doubts exist, 88 whereas the claim is shared to a greater extent in the regionalism scholarship. ${ }^{89}$ The crucial question for the present study is whether profound regional cooperation would be categorically impeded if there were more than one leader. Within the European integration process, Germany and France may possibly prove the opposite, since they, in tandem, have been widely cast as the "engine of European integration." ${ }^{90}$ Nonetheless, Germany has often been a rather reluctant leader, thus avoiding potentially damaging frictions with France,

86 Allison, "Blockaden und Anreize," 263; Laruelle, "Kazakhstan's Dilemma on Eurasian and Central Asian Integration," 397; Timm, "The Security Forces," 381-85.

87 Farkhod Tolipov, "Central Asia: Delayed Consultations, Suspended Integration," The Central Asia-Caucasus Analyst, July 2, 2019, https://www.cacianalyst.org/publications/ analytical-articles/item/13578-central-asia-delayed-consultations-suspended-integra tion.html.

88 See, in particular, Keohane, After Hegemony.

$89 \quad$ E.g., Mattli, The Logic of Regional Integration.

9o Francoise Manfrass-Sirjacques, "Deutschland-Frankreich-Europa-USA. Die Verlagerung der Gewichte und das französische Tauziehen," Dokumente 4 (1992): 275-82, 275. 
with its continuously greater leadership ambitions and embrace of notions of grandeur since the Fifth Republic. Furthermore, both countries have forged a division of labor across issue areas: Germany (also with less overall leadership ambition) acted as a single stabilizer in the realm of economics, whereas France showed leadership in the fields of foreign, security, and military cooperation. This led to progress in integration in both fields of action. Against this backdrop, it might be possible to retain the hegemonic stability argument. Whether similar "division of labor" logics are applicable to Central Asia and other regions beyond the liberal democratic world should be considered an empirically open question.

\section{7}

Conclusion

Security cooperation in Central Asia remains at a moderate level. Where it actually occurs, it involves primarily bilateral or multilateral frameworks nurtured by external state and nonstate partners that have penetrated the region, including its two neighboring superpowers, Russia and China. In contrast, multilateral cooperation among the five states remains weak. Thus far in the security field, regionalism-geographically limited institution-building among three or more states— - has been modest.

Apparently, in view of their power deficits, the Central Asian states themselves are not prepared to manage their regional security to any greater extent. The rational institutionalist perspective suggests that there is a demand for regional security cooperation, particularly to cope with transnational challenges. Thus, there is functional pressure to craft institutional solutions. However, this perspective also implies that it is a rational move for the five states, with their limited resources, to rely largely on external cooperation partners to help provide security solutions in exchange for certain benefits in return. Additional potential causal factors for the low level of self-organization include the lack of accepted single leadership and the "autocratic hesitance" argument that autocracies generally refrain from deep cooperation. The latter cannot be sustained in the case at hand: Kazakhstan and Kyrgyzstan have been consistently in favor of ambitious integration schemes from the outset, leading to intraregional tensions with their hesitant neighbors. Moreover, a significant foreign policy change took place in Uzbekistan, which now displays much greater willingness to engage in (security) cooperation. Depending on the cogency of the hegemonic stability argument, the latter could lead to greater regionalism in the years to come. 
In terms of future research, the insights provided here should be considered to be preliminary rather than definite. The explanatory power of the rational institutionalist account and the relative weight of other causal logics discussed, as well as their interplay, must be further illuminated — both within Central Asia scholarship and in comparative perspective. 